\title{
PENGARUH KETERLIBATAN KERJA DAN ETIKA KERJA TERHADAP \\ ORGANIZATIONAL CITIZENSHIP BEHAVIOR DENGAN \\ ORGANIZATIONAL JUSTICE SEBAGAI \\ VARIABEL INTERVENING \\ (Kasus Pada Pegawai Puskesmas di Kecamatan Guntur, Demak)
}

\author{
Sinar Hubtriyan Ade, Rokhmad Budiyono \\ Fakultas Ekonomi dan Bisnis Universitas Semarang \\ Program Studi Manajemen STIE Semarang
}

\begin{abstract}
The phenomenon that is raised in this study is the low organizational citizenship behavior $(O C B)$ to the employees of the health center in the district of Guntur District Demak. Besides this, the problem of research on which the study is still some discrepancy results from previous studies about factors that affect organizational citizenship behavior $(O C B)$ is a variable work engagement and work ethic are trying constructed with organizational justice. This study aimed to analyze the effects of job involvement and work ethics to organizational justice. And analyze the effect of job involvement, work ethic, and organizational justice on organizational citizenship behavior.

As the population is used as the entire staff of the health center in the district of Guntur District Demak consisting of health centers in the district of Guntur Guntur I and II, which amounted to 102 mployees. Census technique sampling is used within this research. It uses a sample population because the population is relatively little (Sugiyono, 2012). The sample in this study amounted to 102 employees at the health center in the district of Guntur District Demak. Equipment using multiple linear regression analysis using two stages.

These results indicate that the involvement of labor significantly influence organizational justice. The higher the involvement of labor supplied by the organizational justice can be increased. The work ethic has no effect on organizational justice. Job involvement had no effect on organizational citizenship behavior. The work ethic significant effect on organizational citizenship behavior.Organizational justice no significant effect on organizational citizenship behavior. Based on test results show if organizational justice mediation can not mediate effect between work engagement and work ethics to organizational citizenship behavior.
\end{abstract}

Keywords: work involvement, work ethic, organizational justice, organizational citizenship behavior. 


\begin{abstract}
ABSTRAK
Fenomena yang diangkat dalam penelitian ini adalah rendahnya perilaku kewargaan organisasional (OCB) kepada pegawai Puskesmas di Kabupaten Guntur Kabupaten Demak. Selain itu, masalah penelitian yang masih merupakan beberapa hasil perbedaan dari penelitian sebelumnya tentang faktor-faktor yang mempengaruhi perilaku kewargaan organisasional (OCB) adalah variabel kerja keterlibatan dan etos kerja yang mencoba dibangun dengan keadilan organisasional. Penelitian ini bertujuan untuk menganalisis pengaruh keterlibatan kerja dan etika kerja terhadap keadilan organisasional. Dan menganalisis pengaruh keterlibatan kerja, etos kerja, keadilan organisasi terhadap perilaku kewargaan organisasional.

Karena populasi digunakan sebagai keseluruhan staf puskesmas di Kabupaten Guntur Kabupaten Demak yang terdiri dari puskesmas Guntur Guntur I dan II yang berjumlah 102 orang. Teknik samplingnya adalah sensus. Sensus adalah teknik pengambilan sampel yang menggunakan populasi sampel karena populasinya relatif sedikit (Sugiyono, 2012). Sampel dalam penelitian ini berjumlah 102 pegawai di Puskesmas Guntur di Kabupaten Demak. Peralatan menggunakan analisis regresi linier berganda menggunakan dua tahap.

Hasil ini menunjukkan bahwa keterlibatan tenaga kerja secara signifikan mempengaruhi keadilan organisasional. Semakin tinggi keterlibatan tenaga kerja yang dipasok oleh keadilan organisasi dapat ditingkatkan. Etika kerja tidak berpengaruh pada keadilan organisasional. Keterlibatan kerja tidak berpengaruh pada perilaku kewargaan organisasional. Etika kerja berpengaruh signifikan terhadap perilaku kewargaan organisasional. Keadilan organisasi tidak berpengaruh signifikan terhadap perilaku kewargaan organisasional. Berdasarkan hasil pengujian menunjukkan bahwa mediasi keadilan organisasi tidak dapat memediasi pengaruh antara keterlibatan kerja dan etika kerja terhadap perilaku kewargaan organisasional.
\end{abstract}

Kata kunci: keterlibatan kerja, etika kerja, keadilan organisasi, perilaku kewargaan organisasional.

\title{
Pendahuluan
}

Perilaku-perilaku yang senantiasa ditonjolkan di dalam perusahaan saat ini tidak hanya perilaku yang sesuai peranannya saja (in-role) akan tetapi diharapkan dapat lebih memunculkan perilaku extra-role atau organizational citizenship behavior (OCB), sehingga kerjasama tim sebagai nilai penting di dalam sebuah organisasi dapat dipertahankan atau bahkan ditingkatkan. Di samping itu, dengan adanya perilaku extra-role di antara karyawan efektivitas perusahaan akan meningkat. Perusahaan ataupun manajer dapat menghemat beberapa sumber daya 
yang telah dialokasikan sebelumnya apabila perilaku extra-role di antara karyawan berjalan dengan baik. Terlebih lagi pada organisasi atau badan yang berbasis jasa pelayanan kesehatan, salah satunya adalah puskesmas.

Permasalahan yang dialami oleh Puskesmas di Kabupaten Demak yaitu mengenai rendahnya organizational citizenship behavior (OCB) yang ditunjukan oleh data dilapangan bahwa masih adanya keluhan dari pasien yang menggunakan jasa puskesmas. Hal ini terlihat dari data jumlah keluhan pasien (tabel 1.1) :

\begin{tabular}{|c|c|c|c|}
\hline \multicolumn{4}{|r|}{ eriode Tahun 2015} \\
\hline No & Bulan & Jumlah Keluhan & Standar Penilaian Minimal (SPM) \\
\hline 1 & Januari & 33 & 30 \\
\hline 2 & Februari & 32 & 30 \\
\hline 3 & Maret & 25 & 30 \\
\hline 4 & April & 21 & 30 \\
\hline 5 & Mei & 23 & 30 \\
\hline 6 & Juni & 27 & 30 \\
\hline 7 & Ju1i & 29 & 30 \\
\hline 8 & Agustus & 23 & 30 \\
\hline 9 & September & 30 & 30 \\
\hline 10 & Oktober & 41 & 30 \\
\hline 11 & November & 47 & 30 \\
\hline 12 & Desember & 52 & 30 \\
\hline
\end{tabular}

Berdasarkan data diatas, dapat diketahui bahwa secara tidak langsung perilaku ekstra peran (OCB) dari masing-masing individu (dokter, perawat, tenaga medis, dll) pada puskesmas di Kecamatan Guntur, Demak dapat dikatakan masih rendah. Hal tersebut dapat dilihat dari jumlah keluhan yang masuk dari pasien melebihi batas Standar Penilaian Minimal (SPM) yang telah ditetapkan organisasi. Standar Penilaian Minimal (SPM) ini dibuat dengan dasar untuk pengembangan kualitas organisasi.

Rendahnya OCB pada puskesmas di Kecamatan Guntur, Demak didukung hasil pra survey yang dilakukan terhadap pasien yang sedang melakukan antrian untuk berobat di puskesmas yang berjumlah 54 responden. Jumlah 54 responden tersebut diambil berdasarkan jumlah keseluruhan pasien yang datang pada hari dilakukan penyebaran kuesioner pra survey. 
Berikut hasil pra survey berikut :

\begin{tabular}{|c|c|c|c|}
\hline \multicolumn{4}{|c|}{ Pra Survey Penelitian } \\
\hline $\begin{array}{ll}\text { Pertanyaan } & \text { terhadap } \\
\text { responden } & \text { mengenai } \\
\text { OCB } & \end{array}$ & $\begin{array}{l}\text { Jumlah } \\
\text { Responden } \\
\text { Yang } \\
\text { Mengeluh }\end{array}$ & $\begin{array}{l}\text { Jumlah } \\
\text { Responden } \\
\text { Yang } \\
\text { Tidak } \\
\text { Mengeluh }\end{array}$ & $\begin{array}{l}\text { Rata-rata } \quad \text { yang } \\
\text { dikeluhkan responden }\end{array}$ \\
\hline \multirow{3}{*}{$\begin{array}{l}\text { Bagaimana pendapat } \\
\text { saudara mengenai peran } \\
\text { ekstra yang diberikan } \\
\text { pegawai (dokter, } \\
\text { perawat, tenaga medis, } \\
\text { d11) pada puskesmas di } \\
\text { Kecamatan Guntur, } \\
\text { Demak? }\end{array}$} & \multirow[t]{3}{*}{35} & \multirow[t]{3}{*}{$\operatorname{sing}^{2}$} & $\begin{array}{l}\text { kurangnya perawat yang } \\
\text { menjadi asisten dokter } \\
\text { sehingga antrian } \\
\text { konsultasi ke dokter yang } \\
\text { cukup panjang }\end{array}$ \\
\hline & & & $\begin{array}{l}\text { tingginya antrian obat } \\
\text { yang cukup panjang }\end{array}$ \\
\hline & & & D11 \\
\hline
\end{tabular}

Berdasar pada hasil pra survey tersebut mengidentifikasikan bahwa peran ekstra yang diberikan pegawai (dokter, perawat, tenaga medis, dll) pada puskesmas di Kecamatan Guntur, Demak berdampak pada pasien yang belum seluruhnya dapat ditangani dengan baik.

Terdapat beberapa faktor yang berpengaruh terhadap Organizational citizenship behavior (OCB), diantaranya keterlibatan kerja dan etika kerja pegawai. Keterlibatan kerja karyawan adalah sejauh mana seseorang mengidentifikasi secara psikologis dengan pekerjaannya atau pentingnya pekerjaan dalam citra diri individu (Aryaningtyas, 2013). Sedangkan etika kerja merupakan nilai-nilai yang membentuk kepribadian seseorang dalam bekerja (Rokhman, 2010). Namun masih terdapat kesenjangan hasil dari penelitian terdahulu mengenai hal tersebut, yang dapat dilihat pada tabel berikut :

\begin{tabular}{|c|c|c|c|}
\hline \multicolumn{4}{|c|}{ Research Gap } \\
\hline No & Issue / research gap & Peneliti & Hasil \\
\hline \multirow[t]{2}{*}{1} & \multirow{2}{*}{$\begin{array}{l}\text { Kesenjangan hasil } \\
\text { keterlibatan kerja } \\
\text { terhadap } \\
\text { Organizational } \\
\text { citizenship behavior } \\
\text { (OCB) }\end{array}$} & $\begin{array}{l}\text { Saputro, }(2013) \\
\text { dan Fadhilah, } \\
(2014)\end{array}$ & $\begin{array}{l}\text { Keterlibatan kerja berpengaruh } \\
\text { terhadap Organizational } \\
\text { citizenship behavior (OCB) }\end{array}$ \\
\hline & & $\begin{array}{lr}\text { Rifka } & (2013) \\
\text { dan } & \text { Johanes, } \\
(2014) & \end{array}$ & $\begin{array}{lrr}\text { Keterlibatan } & \text { kerja } & \begin{array}{r}\text { tidak } \\
\text { berpengaruh }\end{array} \\
\text { Organizational } & \text { citizenship } \\
\text { behavior (OCB) } & & \end{array}$ \\
\hline \multirow[t]{2}{*}{2} & \multirow{2}{*}{$\begin{array}{l}\text { Kesenjangan hasil } \\
\text { etika kerja terhadap } \\
\text { Organizational } \\
\text { citizenship behavior } \\
\text { (OCB) }\end{array}$} & $\begin{array}{l}\text { Rifka, (2013) } \\
\text { dan Destiana, } \\
(2014)\end{array}$ & $\begin{array}{l}\text { Etika kerja Berpengaruh Terhadap } \\
\text { Organizational citizenship } \\
\text { behavior (OCB) }\end{array}$ \\
\hline & & Johanes, (2014) & $\begin{array}{l}\text { Etika kerja tidak berpengaruh } \\
\text { Terhadap Organizational } \\
\text { citizenship behavior (OCB) }\end{array}$ \\
\hline
\end{tabular}

Berdasarkan tabel diatas dapat dilihat masih adanya perbedaan hasil penelitian terdahulu mengenai faktor yang mempengaruhi Organizational citizenship behavior (OCB) yaitu variabel keterlibatan kerja dan etika kerja, oleh 
karena itu penelitian ini menambahkan variabel organizational justice, yang diharapkan semakin tinggi organizational justice dapat mempengaruhi keterlibatan kerja dan etika kerja pegawai, sehingga perilaku ekstra peran (Organizational citizenship behavior) dari pegawai puskesmas dapat semakin meningkat.

Pentingnya melakukan penelitian mengenai organizational citizenship behavior (OCB) pada pegawai Puskesmas di Kecamatan Guntur Kabupaten Demak, sehingga penelitian ini bertujuan untuk menganalisis pengaruh keterlibatan kerja dan etika kerja terhadap organizational justice. Dan menganalisis pengaruh keterlibatan kerja, etika kerja, organizational justice terhadap organizational citizenship behavior.

\section{Masalah Penelitian}

Dari latar belakang di atas, maka masalah penelitian yang dapat dirumuskan adalah:

1. Apakah keterlibatan kerja berpengaruh terhadap organizational justice

2. Apakah etika kerja berpengaruh terhadap organizational justice

3. Apakah keterlibatan kerja berpengaruh terhadap organizational citizenship behavior

4. Apakah etika kerja berpengaruh terhadap organizational citizenship behavior (OCB)

5. Apakah organizational justice berpengaruh terhadap organizational citizenship behavior (OCB)

\section{Kajian Teoritis}

\section{Organizational citizenship behavior (OCB)}

Menurut Podsakoff et.al. (2000), OCB merupakan bentuk perilaku yang merupakan pilihan dan inisiatif individual, tidak berkaitan dengan sistem reward formal organisasi tetapi secara agregat meningkatkan efektivitas organisasi. 
2. Organizational Justice

Moorman, (1991). Greenberg (1990) mengatakan keadilan organisasi merupakan sebuah konsep yang menyatakan persepsi karyawan mengenai sejauh mana mereka diperlakukan secara wajar, dalam organisasi dan bagaimana persepsi tersebut mempengaruhi hasil organisasi seperti komitmen dan kepuasan.

\section{Keterlibatan Kerja}

Keterlibatan kerja merupakan tingkat sampai sejauh mana individu mengidentifikasikan dirinya dengan pekerjaannya, secara aktif berpartisipasi di dalamnya, dan menganggap performansi yang dilakukannya penting untuk keberhargaan dirinya (Hiriyappa, 2009).

\section{Etika Kerja}

Menurut Suseno 1987, etika adalah suatu ilmu yang membahas tentang bagaimana dan mengapa kita mengikuti suatu ajaran moral tertentu atau bagaimana kita harus mengambil sikap yang bertanggung jawab berhadapan dengan pelbagai ajaran moral.

\section{Metodologi}

1. Kerangka Pemikiran

Pemaparan kerangka pemikiran dapat dijelaskan melalui perumusan hipotesis mengenai variabel keterlibatan kerja, etika kerja dan organizational justice terhadap organizational citizenship behavior (OCB), sebagai berikut :

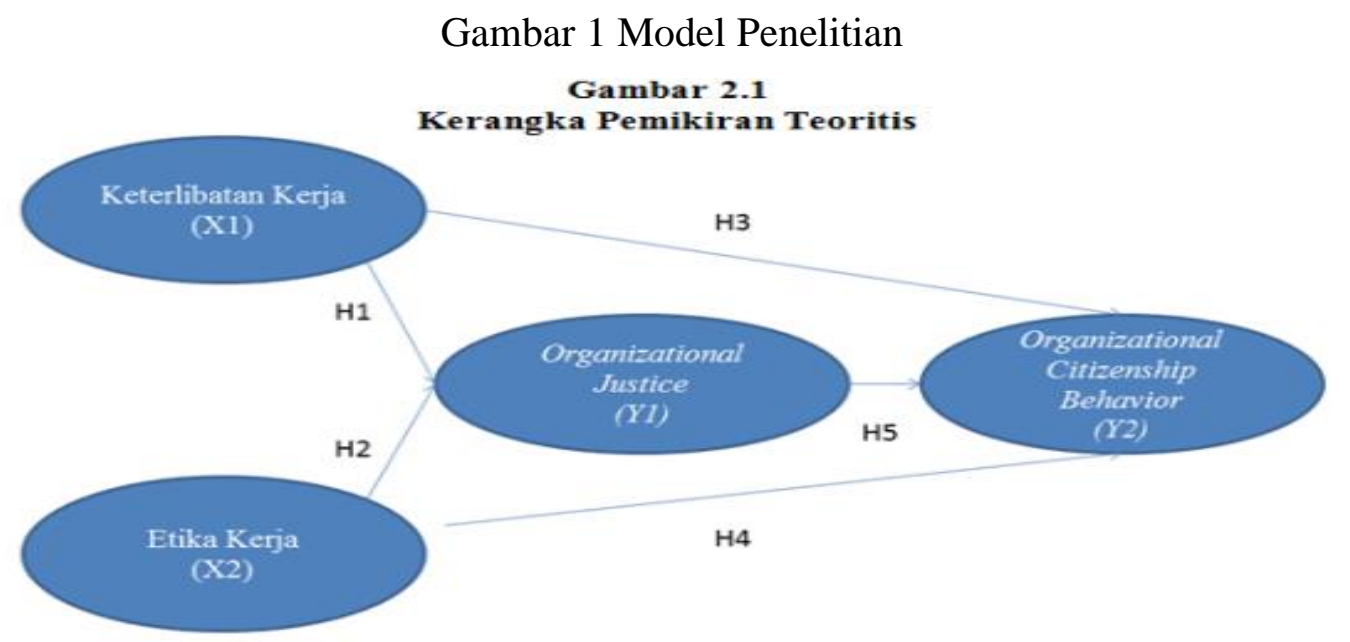


2. Pengembangan Hipotesis

$\mathrm{H}_{1}$ : Keterlibatan kerja Berpengaruh Terhadap Organizational justice

$\mathrm{H}_{2}$ : Etika kerja Berpengaruh Terhadap Organizational justice

$\mathrm{H}_{3}$ : Keterlibatan kerja Berpengaruh Terhadap Organizational citizenship behavior

$\mathrm{H}_{4}$ : Etika kerja Berpengaruh Terhadap Organizational citizenship behavior (OCB)

$\mathrm{H}_{5}$ :Organizational justice Berpengaruh Terhadap Organizational citizenship behavior (OCB)

3. Populasi dan Sampel

Adapun yang dijadikan sebagai populasi adalah seluruh pegawai Puskesmas di Kecamatan Guntur Kabupaten Demak yang berjumlah 102 pegawai.Teknik sampling adalah sensus atau menggunakan keseluruhan populasi sebagai sampel.

4. Jenis dan Sumber Data

Data primer penelitian ini diperoleh dari pembagian kuesioner yang diberikan kepada karyawan Puskesmas di Kecamatan Guntur Kabupaten Demak, yang meliputi Kepala Puskesmas, Kasubag. TU, Dokter Umum, Dokter Gigi, Sanitarian, Asisten Apoteker, Bidan, Perawat, Perawat Gigi, Nutrisionis, Analis Kesehatan, Promoter Kesehatan, Staf Umum Administrasi, Staf Umum Kebersihan, Staf Penjaga Malam.

5. Metode Pengumpulan Data

Metode pengumpulan data menggunakan kuesioner dengan skala 1-10 maka varibel yang akan diteliti dan dijabarkan menjadi indikator variabel.

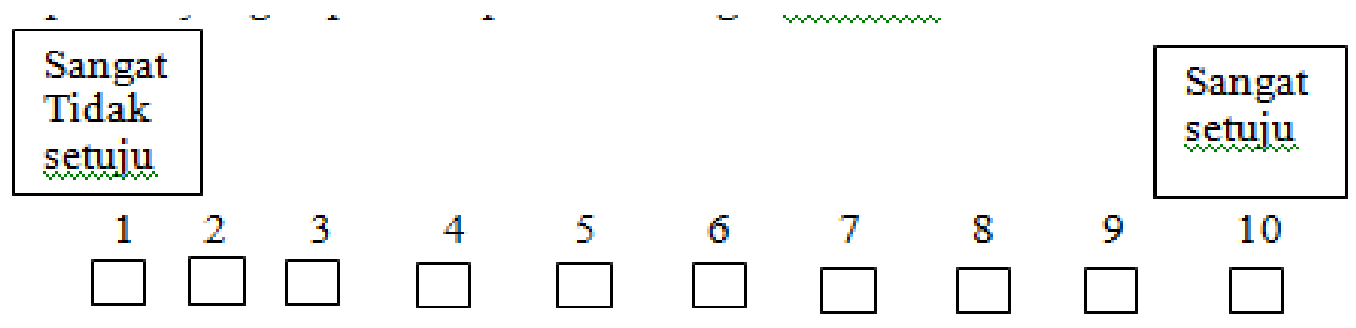


6. Metode Analisis

1) Uji Validitas

Pengujian validitas dilakukan dengan menggunakan uji Kaiser-Meyer-Olkin Measure of Sampling Adequacy.Nilai KMO > 0,5 dan memiliki nilai loading faktor yang tinggi dari 0,4 .

2) Uji Reliabilitas

Suatu data dikatakan reliabel adalah variabel memiliki nilai Cronbach alpha 0,70 (Ghozali, 2013).

3) Uji Normalitas

Model regresi dikatakan berdistribusi normal dengan cara membandingkan nilai kolmogorov smirnov > 0,05 Ghozali, (2013).

4) Uji Multikolinieritas

Bertujuam untuk menguji model regresi ditemukan adanya korelasi antara variabel bebas Ghozali (2013).

a. Jika nilai tolerance $>$ dari nilai 0,1 dan nilai VIF $<$ dari nilai 10 maka tidak ditemukan adanya multikolinieritas.

b. Jika nilai tolerance $<$ dari 0,1 dan nilai VIF $>$ dari nilai 10 maka ditemukan adanya multikolinieritas.

5) Uji Heteroskedastasitas

Bertujuan menguji apakah dalam model regresi terjadi ketidaksamaan variance dari residual satu pengamatan ke pengamatan yang lain (Ghozali, 2013). uji heterokedastisitas menggunakan uji glejser menunjukan jika nilai probalitas signifikasinya di atas tingkat kepercayaan 5\% jadi dapat disimpulkan model regresi tidak mengandung adanya heteroskedastisitas.

6) Analisa Regresi Linier Berganda Dua Tahap

Regresi linier berganda digunakan untuk mengetahui besarnya pengaruh Keterlibatan kerja, Organizational justice, terhadap Organizational citizenship behavior (OCB) ataupun melalui Organizational justice sebagai variabel intervening Ghozali (2013). Adapun persamaan model regresi berganda dengan dua persamaan adalah:

$\mathrm{Y} 1=\beta_{1} \mathrm{X}_{1}+\beta_{2} \mathrm{X}_{2}+\mathrm{e}$ 
$\mathrm{Y} 2=\beta_{3} \mathrm{X}_{1}+\beta_{4} \mathrm{X}_{2}+\beta_{5} \mathrm{Y}_{1}+\mathrm{e}$

Keterangan :

Y2 : Organizational citizenship behavior (OCB)

Y1 : Organizational justice

$\beta_{1 . .} \beta_{3}$ : Koefisien Regresi

$\mathrm{X}_{1} \quad$ : Keterlibatan kerja

$\mathrm{X}_{2} \quad$ : Etika kerja

e : Error (koefisien penganggu)

7) Pengujian hipotesis

Untuk mempengaruhi variabel yang berpengaruh antar $\mathrm{X}_{1}, \mathrm{X}_{2}, \mathrm{X}_{3}$ terhadap $\mathrm{Y}$ secara individual (parsial) maka di gunakan Uji t. Adapun kriteria pengujian uji t adalah sebagai berikut:

a. Jika Sig < 0,05 maka Ho ditolak dan Ha diterima ada pengaruh signifikan variabel independen secara individual terhadap variabel dependen

b. Jika Sig > 0,05 makan Ha ditolak dan Ho diterima berarti tidak ada pengaruh signifikan variabel independen secara individual terhadap variabel dependen.

8) Koefisien Determinasi $\left(\mathrm{R}^{2}\right)$

Koefisien determinasi $\left(\mathrm{R}^{2}\right)$ pada intinya mengukur seberapa jauh kemampuan model dalam menerangkan variabel-variabel dependen.

9) Uji Efek Mediasi (Sobel test)

Sobel test merupakan alat untuk menguji seberapa besar kedudukan suatu variabel mediasi (intervening) atau efek tidak langsung yang ditimbulkan oleh variabel mediasi (intervening) (Ghozali, 2013)

a. Efek Langsung- Efek langsung X terhadap Y dapat diketahui melalui jalur-c

b. Efek Tidak Langsung - Efek tidak langsung X terhadap Y dapat diketahui melalui perkalian antara jalur -a dan jalur - $b$ (jalur-ab).

\section{Pembahasan}


Regresi Linier Berganda 2 Tahap

Persamaan Regresi Linier Berganda 1

\begin{tabular}{|c|c|c|c|c|c|c|c|}
\hline \multicolumn{8}{|c|}{ Coefficients $^{\mathrm{a}}$} \\
\hline \multirow[b]{2}{*}{ Model } & \multicolumn{2}{|c|}{$\begin{array}{l}\text { Unstandardized } \\
\text { Coefficients }\end{array}$} & \multirow{2}{*}{\begin{tabular}{|c|}
$\begin{array}{c}\text { Standardized } \\
\text { Coefficients }\end{array}$ \\
Beta \\
\end{tabular}} & \multirow[b]{2}{*}{$\mathrm{t}$} & \multirow[b]{2}{*}{ Sig. } & \multicolumn{2}{|c|}{$\begin{array}{c}\text { Collinearity } \\
\text { Statistics }\end{array}$} \\
\hline & $\mathrm{B}$ & Std. Error & & & & Tolerance & $\mathrm{VIF}$ \\
\hline 1 (Constant) & 22,174 & 3,427 & & 6,470 &, 000 & & \\
\hline keterlibatan kerja &, 370 & 150 & ,293 & 2,464 &, 015 & ,606 & 1,651 \\
\hline etika kerja & 193 & 178 & ,129 & 1,087 & 280 & ,606 & 1,651 \\
\hline
\end{tabular}

\section{Persamaan Regresi Linier Berganda 2}

\begin{tabular}{|c|c|c|c|c|c|c|c|}
\hline \multicolumn{8}{|c|}{ Coefficients $^{\mathrm{a}}$} \\
\hline \multirow[b]{2}{*}{ Model } & \multicolumn{2}{|c|}{$\begin{array}{c}\text { Unstandardized } \\
\text { Coefficients }\end{array}$} & \multirow{2}{*}{\begin{tabular}{|c|}
$\begin{array}{c}\text { Standardized } \\
\text { Coefficients }\end{array}$ \\
Beta \\
\end{tabular}} & \multirow[b]{2}{*}{$t$} & \multirow[b]{2}{*}{ Sig. } & \multicolumn{2}{|c|}{ Collinearity Statistics } \\
\hline & $B$ & Std. Error & & & & Tolerance & VIF \\
\hline 1 (Constant) & 19,211 & 3,527 & & 5,446 &, 000 & & \\
\hline keterlibatan kerja & 206 & , 133 & , 179 & 1,546 & , 125 &, 571 & 1,752 \\
\hline etika kerja &, 457 & , 155 &, 335 & 2,960 &, 004 &, 599 & 1,671 \\
\hline organizationaljustice &, 066 &, 087 &, 073 &, 766 &, 446 &, 850 & 1,177 \\
\hline
\end{tabular}

Persamaan $\mathrm{Y}_{2}=0,179 \mathrm{X}_{1}+0,335 \mathrm{X}_{2}+0,073 \mathrm{X}_{3}$

Koefisien Determinasi $\left(\mathrm{R}^{2}\right)$

Model Summary ${ }^{b}$

\begin{tabular}{|l|l|r|r|c|}
\hline Model & $\mathrm{R}$ & $\begin{array}{c}\mathrm{R} \\
\text { Square }\end{array}$ & $\begin{array}{c}\text { Adjusted } \mathrm{R} \\
\text { Square }\end{array}$ & $\begin{array}{c}\text { Std. Error of the } \\
\text { Estimate }\end{array}$ \\
\hline 1 &, $388^{\mathrm{a}}$ &, 150 &, 133 & 3,657 \\
\hline
\end{tabular}

a. Predictors: (Constant), etika kerja, keterlibatan kerja

b. Dependent Variable: organizational justice

Pada model sumary tahap 1 dapat dilihat jika nilai adjust R2 sebesar 0,133, artinya 13,3\% organizational justice dapat dipengaruhi oleh keterlibatan kerja dan etika kerja.

Model Summary
\begin{tabular}{|l|c|r|r|r|}
\hline Model & R & R Square & $\begin{array}{c}\text { Adjusted R } \\
\text { Square }\end{array}$ & $\begin{array}{c}\text { Std. Error of the } \\
\text { Estimate }\end{array}$ \\
\hline 1 &, $500^{3}$ &, 250 &, 227 & 3,155 \\
\hline
\end{tabular}

a. Predictors: (Constant), organizational justice, etika kerja, keterlibatan kerja

b. Dependent Variable: organizational citizenship behavior 
Pada model sumary tahap 2 dapat dilihat jika nilai adjust R2 sebesar 0,227, artinya $22,7 \%$ OCB dapat dijelaskan oleh keterlibatan kerja, etika kerja dan organizational justice.

\section{Pengaruh Secara Langsung}

Hubungan Antara Keterlibatan kerja Terhadap Organizational justice

Berdasarkan hasil perhitungan yang telah dilakukan, maka diperoleh nilai signifikansi sebesar $0,015<0,05$. Hal ini menunjukkan keterlibatan kerjaberpengaruh signifikan terhadap Organizational justice.Semakin tinggi keterlibatan karyawan pada organisasi akan mendapat kepercayaan penuh dari organisasi dalam pelaksanaan program yang berdampak pada tingkat pemberian jasa, sehingga Organizational justice akan meningkat.

\section{Hubungan Antara Etika kerja Terhadap Organizational justice}

Berdasarkan hasil perhitungan yang telah dilakukan, maka diperoleh nilai signifikansi sebesar $0,280<0,05$. Hal ini menunjukkan etika kerjatidak berpengaruh terhadap Organizational justice. Berdasar pada hasil kuesioner terbuka menunjukan bahwa dalam pemberian jasa layanan tidak dilihat dari etika kerja yang meliputi kepercayaan yang diberikan organisasi terhadap karyawan, kejujuran karyawan dalam menjalankan pekerjaan serta pekerjaan yang diselesaikan secara efektif dan efisien namun keadilan organisasi ini dilihat dari pendidikan, kehadiran, tanggung jawab program dan jabatan, beban kerja, jadi dapat disimpulkan ada tidaknya etika kerja tidak mempengaruhi peningkatan Organizational justice yang tidak termasuk pada kriteria pemberian jasa layanan.

Hubungan Antara Keterlibatan kerja Terhadap Organizational citizenship behavior

Berdasarkan hasil perhitungan yang telah dilakukan, maka diperoleh nilai signifikansi sebesar 0,125>0,05. Keterlibatn tidak berpengaru terhadp keadilan kerja. Dengan alasan karena karakteristik individual tidak mengaharapkan upah, yang berfokus pada keiklasan menolong. 


\section{Hubungan Antara Etika kerja Terhadap Organizational citizenship behavior}

Berdasarkan hasil perhitungan yang telah dilakukan, maka diperoleh nilai signifikansi sebesar $0,004<0,05$. Hal ini menunjukkan etika kerja berpengaruh signifikan terhadap organizational citizenship behavior.Karyawan yang memiliki etos kerja yang baik, secara tidak langsung memiliki peran lebih dalam tugasnya didalam organisasi.

Hubungan Antara Organizational justice Terhadap Organizational citizenship behavior

Berdasarkan hasil perhitungan yang telah dilakukan, maka diperoleh nilai signifikansi sebesar 0,446<0,05. Hal ini menunjukkan Organizational justice tidak berpengaruh terhadap organizational citizenship behavior. Rasa adil dan tidak adil dalam organisasi tidak mempengaruhi karakter individu dalam melakukan peran lebih. Meskipun merasa tidak adil dalam organisasi tetapi karyawan dengan iklas melakukan peran ekstra sebagai bentuk rasa solidaritas.

\section{Pengaruh Secara Tidak Langsung}

Hasil pengujian mediasi menunjukan jika Organizational justice tidak mampu memediasi antara keterlibatan kerja dan etika kerja terhadap organizational citizenship behavior. Hal ini dikarenakan Puskemas merupakan lembaga yang dibentuk oleh Pemerintah sehingga kebijakan yang diberikan Puskesmas sesuai dengan kebijakan Pemerintah, meskipun karyawan merasa membutuhkan keadilan kerja namun karyawan juga tidak mampu berbuat apa-apa. Sehingga karyawan hanya menjalankan pekerjaan sesuai dengan aturan yang diberlakukan.

\section{Kesimpulan}

Berdasarkan penelitian yang telah dilakukan maka dapat diperoleh kesimpulan sebagai berikut : 
1. Keterlibatan kerja berpengaruh signifikan terhadap Organizational justice. Semakin tinggi keterlibatan kerja yang dilakukan karyawan seperti terlibat dalam pekerjaan, terlibat dalam kegiatan organisasi dan terkait antara pekerjaan dengan tujuan hidup, maka Organizational justice dapat meningkat.

2. Etika kerja tidak berpengaruh terhadap Organizational justice. Hal ini dikarenakan dalam pemberian jasa layanan tidak dilihat dari etika kerja, namun hanya dilihat dari pendidikan kehadiran, tanggung jawab program dan jabatan, beban kerja, jadi ada tidaknya etika kerja tidak mempengaruhi peningkatan Organizational justice yang tidak termasuk pada kriteria pemberian jasa layanan.

3. Keterlibatan kerja tidak berpengaruh terhadap organizational citizenship behavior. Hal ini dikarenakan karakteristik individual setiap karyawan dalam keterlibatan kerja tidak mengaharapkan upah, hanya berfokus pada keiklasan menolong.

4. Etika kerja berpengaruh signifikan terhadap organizational citizenship behavior. Semakin baik etika kerja karyawan seperti menjaga kepercayaan dari pasien ataupun atasan, kejujuran dalam menjlankan pekerjaan, dan smart, maka semakin meningkat organizational citizenship behavior .

5. Organizational justice tidak berpengaruh signifikan terhadap organizational citizenship behavior. Hal ini dikarenakan rasa adil dan tidak adil dalam organisasi tidak mempengaruhi karakter individu dalam melakukan peran lebih. Meskipun merasa tidak adil dalam organisasi tetapi karyawan dengan iklas melakukan peran ekstra sebagai bentuk rasa solidaritas.

6. Berdasarkan hasil pengujian mediasi menunjukan jika Organizational justice tidak dapat memediasi pengaruh antara keterlibatan kerja dan etika kerja terhadap organizational citizenship behavior.

\section{Daftar Pustaka}

As'ad, Moh. 1986, Kepemimpinan Efektif dalam Perusahaan, Edisi 2, Liberty, Yogyakarta. 
Ade, (2011). Pengaruh Keterlibatan Kerja dan Etika kerja Terhadap Organizational justice di Asuransi kesehatan, Malang). Jurnal Ekonomi. Vol 17 no 2 p: 39-53.

Destiana, (2014) Analisis Ethos kerja dan Organizational justice Terhadap Organizational Citizenship Behavior (Studi pada Karyawan Kompartemen Pabrik II PT. Petrokimia Gresik)”. Jurnal Administrasi Bisnis. vol. 21: hal: $1-8$.

Dyne dan Ang, 1998 A Framework for Human Resource Management, NewJersey: Pearson Education Inc

Fadhilah, (2014), Pengaruh Antara Keterlibatan Kerja terhadap Organizational citizenship behavior (OCB) di Universitas Muhammadiyah Surakarta (UMS). Jurnal Manajemen dan Kewirausahaan Volume 10 Nomor 2 September 2014

Flippo, Edwin B., (terjemahan Moh. Mas'ud), 1994, Manajemen Personalia Jilid 1, Erlangga, Jakarta.

Ghozali, Imam, 2013, Aplikasi Analisis Multivariate dengan Program SPSS, BPFE Undip, Semarang.

Gomes, Faustino Cardoso, 2006, Manajemen Sumber Daya Manusia, Edisi 2 Cetakan 1, Andi Offset, Yogyakarta.

Gordon, Judith R., 1996, Perilaku Organisasional, Penerbitan UAJY, Yogyakarta.

H. Donelly, Jr., (terjemahan Nunuk Ardiani), 1996, Organisasi : Perilaku, Struktur, Proses Jilid 1, Edisi 8 Cetakan 1, Binarupa Aksara, Jakarta.

Handoko, Hani. 2008. Manajemen Personalia. BPFE Yogyakarta : Yogyakarta.

James A. F. Mathis. Alfonsus Jackson, 2006, Manajemen Jilid I, Edisi 8, Erlangga, Jakarta.

Johanes, (2014), Pengaruh Keterlibatan Kerja, komitmen organisasi dan Etika Kerja terhadap Organizational citizenship behavior (OCB) di Rumah Sakit Sultan Agung, Semarang. Jurnal Manajemen dan Bisnis. Volume 1 Nomor 3 Tahun 2014

Luthan. 2006. Organisasi dan Motivasi. Cetakan Keempat. Bumi Aksara. Jakarta.

Noe, Raymond, 2005. Employee Training and Developent, New York: McGrawHill Companies Inc.

Rivai Veithzal, 2009, Manajemen Sumber Daya Manusia untuk Perusahaan, PT. Grafindo Persada. Jakarta. 
Ratnawati, (2013), Pengaruh Keadilan Organisasional, Kepercayaan Pada Atasan Terhadap Perilaku Kewargaan Organisasi (Organizational Citizenship Behavior)

Rifka, (2013), Pengaruh Keterlibatan Kerja, Etika Kerja, otonomi, komitmen kerja dan kepuasan kerja terhadap Organizational citizenship behavior (OCB) studi kasus di Rumah Sakit (X) di Bandung

Robbins. 2008. MANAJEMEN Edisi Kesepuluh jilid 1. Jakarta : Erlangga 